\title{
THE IDENTIFICATION OF THE VALACH CLIMATIC CYCLE - IMPORTANT ACHIEVEMENT OF ROMANIAN GEOLOGICAL RESEARCH SCHOOL
}

\author{
MIRCEA ȚICLEANU ${ }^{1}$, NICOLAE ȚICLEANU ${ }^{2}$, PAUL CONSTANTIN ${ }^{1}$, \\ SIMON PAULIUC ${ }^{2} \&$ FLORIAN MARINESCU ${ }^{1}$
}

\begin{abstract}
The paper summarises the main consequences resulting from the identification of a new climatic cycle. The new cycle, referred to as "The Valach Cycle" (nom. nov., Prague, 1998), has a period of about 4.1 m.y., and its warming and cooling phases can be traced for a period of minimum 86 m.y., up to Santonian (inclusive). More exactly, the paper suggests that this new cycle can be a direct consequence of pulsation of the Solar system - a newly identified cosmic movement to which we refer to as the "Valach pulsation". This paper also refers to the previous research studies in this field - i.e. Steininger et al., 1988 (Austria) and Moisescu 1990, 1994 (Romania).
\end{abstract}

KEY WORDS: Valach climatic cycle, coal facies, coal-generating phases, lignitophile phases, Valach pulsation, Quaternary glaciation, Romania

\section{INTRODUCTION}

We imagined in this paper a climatic cycle explaining the succession of coal-generating phases of Neogene based on our observing of a climatic climax placed in the Lower Romanian stage. We made this observation during our detailed research of Pliocene (Dacian-Romanian) coal facies, research especially focused in the west part of the Dacic Basin (Oltenia). We corroborated this climax with the minimum reached in the Riss alpine phase, as well as with the warm phases of a climatic cycle explaining the other coal-generating phases of Neogene, and those of Miocene (Pontian, Portaferrian, Sarmatian, Badenian, Burdigalian, and Chattian-Aquitanian). Consequently, we were able to calculate the extent of this climatic cycle, which was approximated to 4.1 m.y., the cycle itself being named "The Valach Cycle" (nom. nov., Ticleanu et al., 1998).

The re-evaluation of Paleogene coal facies of north-western Transylvania allowed us to add three more warm phases of the Valach cycle, corresponding to coal-generating phases of Uppermost Eocene and Oligocene. Their stratigraphic position is as follows: Priabonian - Lowermost Rupelian (the coal of Morlaca and the seams of Curtuiuș), Middle Rupelian (the seams of Cetate), and Lower Chattian (the upper seams of Zimbor)(Ticleanu et al., 2002).

${ }_{1}^{1}$ Geological Institute of Romania, 1 Caransebeș Street, 78344 Bucharest; E-mail: paulct@igr.ro

${ }^{2}$ Faculty of Geology and Geophysics, Bucharest University, 1 Blvd. N. Balcescu, 70111 Bucharest 
The coal-generating phase of Thanetian (Upper Palaeocene), known in the Paris and Pannonic basins confirms the clear-cut action of the Valach cycle during Eocene, its warm phases leading to coal-generating phases during Lutetian and Bartonian (western Europe and the Russian Platform).

Finally, the existence of coal facies in sub-phases of Senonian (Santonian - Vad-Borod Basin; Lower and Middle Maastrichtian - Rusca Montană Basin) allows us to conclude that the Valach cycle manifested itself from the end of the Cretaceous up to the Quaternary for a period of minimum 86 m.y. (Ticleanu et. al., 2002) (fig. 1).

The identification of the Valach cycle allows us to underline the existence of periodic pulsation of the Solar system explaining thus the periodic warming and cooling of the external layers of the Earth, which are directly linked to the aforesaid succession of coal-generating phases. However, the consequences of what we consider a remarkable achievement in this field are only summarised within this paper. Consequently, we will refer to these pulsation phenomena as the "Valach pulsation".

We also take this opportunity to underline the near results of research obtained by a group of Austrian geologists lead by Steininger (1988), and the results of Moisescu $(1990,1997)$, in connection with the Paleogene coal facies of Transylvania, however both researches not properly finalised from our perspective.

Nevertheless, we consider this research still far from finalisation as we underline the necessity of furthering these studies into the effects of the Valach cycle in ante-Cainozoic times, on one hand, and on the other, the need for more detailed studies of Senonian and Tertiary (Cainozoic) deposits that reflect, in our opinion, the warming phases of the Valach cycle (synchronic coal and salt facies), as well as the cooling phases (coarse deposits, usually red in colour, synchronised with the proliferation of glaciers).

\section{PREVIOUS RESEARCH STUDIES}

Among such studies we need to mention on one hand the study published in 1988 by a group of Austrian geologists lead by Steininger, and on the other hand, the studies published by Moisescu in 1990 and 1994 regarding coal-bearing deposits of north-western Transylvania.

Steininger et al. (1988), in their research of coal facies in Tertiary deposits of Austria, have underlined the existence of periods favourable to formation of coal facies, which we referred to as "lignitophile phases", for an interval stretching from Upper Eocene (Priabonian) to Pontian. Moreover, having a perspective on transgressive-regressive cycles of Paratethys and on global eustatic cycles of the interval Eocene-Pliocene imagined by Haq et al. (1987), the authors underline the link between these "lignitophile phases" and transgressive moments of Tertiary. However, the Austrian researchers do not question the problem of the temporal content of cycles corresponding to these tertiary "lignitophile phases" and get to imagine three so called cycles responsible of 86 
the formation of coal complexes they have researched. They named these cycles "Gosau cycle", the "molasses cycle", and the "cycle of inter-mountainous basins", respectively. However, it is our view that these distinctions are not helpful in researching this domain.

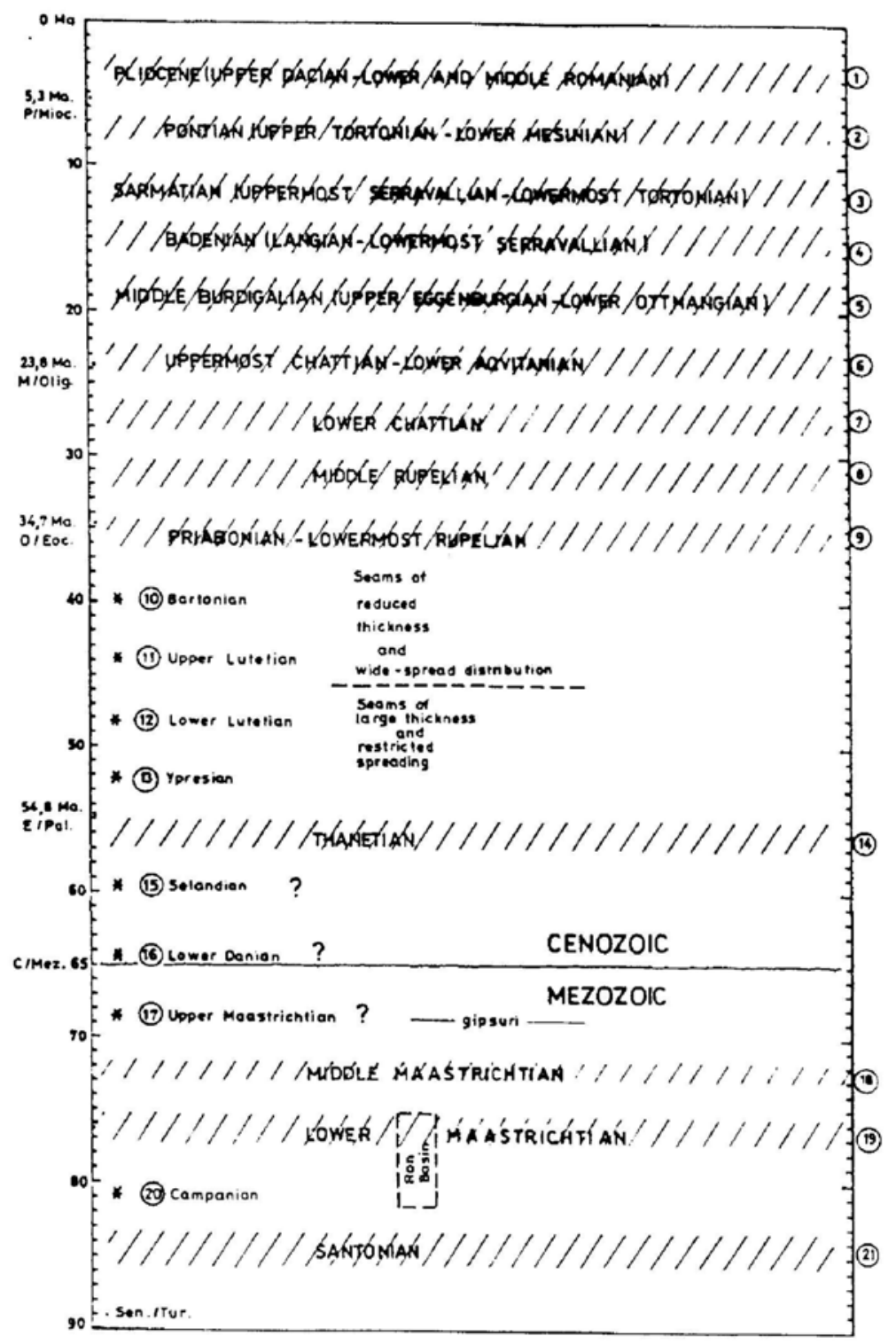

Fig. 1 The coal-generating phases of Santonian-Pliocene in Parathetys 
In Romania, Moisescu has researched, from the perspective of sedimentary cycles apparent in north-western Transylvania, on one hand, the interval of Upper Lutetian - Pribonian (Moisescu, 1990), and on the other, the interval of Priabonian - Burdigalian. At the level of this last time-interval Moisescu (1994) underlines five (5) sedimentary cycles corresponding to the formations belonging to Priabonian, Merian, Chattian, Aquitanian and Burdigalian, which could extend temporally from 38.5 to 16.5 m.y. The author, however, has not been preoccupied by the periodic character of these sedimentary cycles, and therefore, he did not make any mention as regards this character. If we consider, however, the time-interval covered by the aforesaid five (5) cycles, which is 22 million years (38.5 - 16.5 m.y.), then, assuming a periodical repetition of said sedimentary cycles, we could get a period of 4.4 m.y. for these cycles, as opposed to $4.1 \mathrm{~m} . \mathrm{y}$., the period of Valach cycle. Moreover, is interesting to mention that in the aforesaid time-interval can be underlined five (5) distinct coal-generating phases. These phases correspond from a stratigraphic point of view to Priabonian, Lowermost Rupelian, Middle Rupelian, Lower Chattian, Uppermost Chattian, and Middle Burdigalian, the five coal-generating phases coinciding with the sedimentary cycles underlined by the author.

\section{THE CONSEQUENCES OF IDENTIFYING THE VALACH CYCLE}

It is our opinion that this perspective on Earth's climatic evolution, for a period of about 90 million years, allows the clarification of some important aspects within Earth's geological evolution, at least for the considered interval. Among the consequences, we enumerate the following: identification of a new cosmic movement: the pulsation of the Solar system (pulsation to which we refer as "Valach pulsation"); the explanation of Quaternary glacial period as the last cooling phase of the Valach cycle; easy justification of important Cainozoic transgressions and regressions; easy explanation of Neozoic and Senonian coal-generating phases; evidencing the effects of the last "galactic winter" by absence of some phases of the Valach cycle near the limit between Cretaceous and Tertiary; imposing the climatic factor as determinant in the occurrence of coal-generating phases; imposing a new perspective on the inferior cycles of the Valach cycle, responsable, in our opinion, by the occurrence of coal seams.

\footnotetext{
3.1. Identification of a new cosmic movement: the pulsation of the Solar system (pulsation to which we refer as "Valach pulsation")

Conceiving a potential pulsation of the Solar system represents an optimum solution as to the dynamic causes of the Valach climatic cycle, these being the singular causes that could lead, plausibly, to the warming and cooling phases of this cycle. In practical terms, the closing of the planets to the Sun, representing a contraction of the Solar system, could lead to a direct warming of the Earth's external layers. This warming would cause a melting of shelf glaciers, followed by a global transgression movement, accompanied also by increased humidity on large areas. All these favour, given the appropriate paleo-geographic
} 88 
conditions, a luxuriant development of vegetation, corresponding to the warming phase of the Valach climatic cycle. Vice-versa, the distancing of the planets from the Sun, corresponding to an expansion of the Solar system, determines a cooling of the Earth's external layers, followed inevitably by a proliferation of shelf glaciers, which attracts a global regression movement, followed by reduced humidity and development of vegetation, corresponding to the cooling phase of the Valach cycle.

It is obvious that given the relatively large period of the Valach cycle (about 4.1 m.y.), it is very difficult to make direct astronomical observations. However, it is quite easy to deduct such pulsation phenomena considering its long-term effects on the Earth's external layers.

3.2. The explanation of Quaternary glacial period as the last cooling phase of the Valach cycle. This explanation is very important considering the Earth's evolution for the past million years. On a different level, it is extremely important to estimate the general evolution of the climate within the next evolution stage of our planet. The Quaternary glacial period is very easily explained if looked at as the last cooling phase of the Valach climatic cycle, during which occurred naturally, a proliferation of polar glaciers to lower latitudes and, in mountainous areas, towards lower altitudes, especially during the specific glacial stages. If we consider the surpassing of the last climatic minimum of the Valach cycle, which was the Riss glacial stage, we can understand that the Earth entered in the second part of the last cooling phase of the Valach cycle. This will potentially lead the planet for the following million years towards a new warming phase of this cycle.

3.3. Easy justification of important Neozoic transgressions and regressions. Viewing things from the Valach cycle perspective we can easily explain, thanks to the warming phases of this cycle, all Neozoic transgressions leading to the apparition of lacustrine facies and the humid climate favourable to development of abundant vegetation (Steininger et al., 1985; Ticleanu et al., 2001). At least for the Neogene coal-generating phases we can remark that coalbearing deposits often occupy larger surfaces than sterile deposits preceding them. A very good example to this extent is the Portaferrian coal facies synchronised with the last possible link between Dacic and Pannonic Basins, at the same level with deposits bearing Congeria rhomboidea rhomboidea, otherwise impossible unless for the occurrence of an important transgression stage.

3.4. Easy explanation of Neozoic and Senonian coal-generating phases. Explanation of the mechanism of occurrence and development of successive Cainozoic coal-generating phases is another important consequence of the Valach climatic cycle. In this way is possible the exclusion as improbable of all hypothesis trying to explain the occurrence of coal facies and their characteristics (among which, the idea migrating coal facies). Furthermore, it becomes obvious that the Valach cycle can explain the coal-generating phases of Uppermost 
Cretaceous (Țicleanu et al., 2002). This development leads to further analysis opportunities of Lower Cretaceous coal-generating phases around the Earth, as well as new openings regarding coal-generating phases at the level of Liasic coal-bearing deposits in Romania.

Nevertheless, the explanation of successive coal-generating phases leads to a more comprehensive understanding of sterile phases intermingling with the former, and which are linked to coarse deposits rich in iron oxides giving them the characteristic red colour.

3. 5. Evidencing the effects of the last "galactic winter" by absence of some phases of the Valach cycle near the limit between Cretaceous and Cainozoic. The absence of warming phases of the Valach cycle at the limit between Cretaceous and Cainozoic, and the lacking of coal-generating phases in Upper Maastrichtian and in Lower and Middle Palaeocene (Danian and Selandian), clearly evidences the unfavourable effect induced in Earth's biosphere by the cooling phase of an important cycle, superior in order one (the Galactic Cycle). (We referred in previous studies to this period as the "Galactic Winter"). This situation is also a very good example as to the relations established between cycles of different natures and with different periods. In this particular phase, the cooling phase of the galactic cycles supersedes the warming phases of the Valach climatic cycle near the limit between Cretaceous and Tertiary to such an extent that during the latter's warming phases there was no significant warming of the Earth. This lead to poor conditions for the occurrence of coal facies, although there is a possibility, still unconfirmed, that feebly representation of these warming phases might have occurred in some regions of the Earth.

3.6. Imposing the climatic factor as determinant in the occurrence of coal-generating phases. The Valach cycle allows the viewing of the climatic factor as determining factor in the occurrence and development of coal facies, at least concerning the coal-generating phases of Cainozoic and Senonian. Without this factor, it is our opinion, there could be no proper explanation as to the strict periodic repetition of coal-generating phases. Therefore, we consider the climatic conditions (temperature and humidity) instrumental in the formation and development of coal facies, and only afterwards, may come other factors, particularly the paleo-geographic one. From this perspective, we consider the structural factor a far less important one. That is because the mechanism leading to formation of coal seams is not linked to repeated processes of lowering of lake basins, but to transgressions and regressions with smaller amplitudes, controlled by climate (the cycles with a period of about 100,000 million years). Moreover, if climate controls the repetition of coal-generating phases, the paleo-geographic factor controls the spatial extent of coal facies, whereas the internal structure of coal-bearing deposits being set to detail by the structural factor. Finally, the evolution level reached by continental flora at one moment in time reflects in the paleo-floristic coal-generating associations, which differ from one coal-generating phase to another. 
3.7. Imposing a new perspective on the inferior cycles of the Valach cycle, responsible in our opinion by the occurrence of coal seams. If we consider the period during which extends the warming phase of the Valach cycle, at the level of each coal-generating phase, situated around two (2) million years, we can appreciate the role played by inferior cycles in establishing the textural configuration of coal facies. Considering the number of main coal seams specific to some coal-generating phase (between 18-20 and 25-27 seams), it has been underlined (Țicleanu et al, 1998; Țicleanu, 1999) that the occurrence of such coal seams is strictly linked with the warming phases of the shorter cycles of the orbital eccentricity (with a period of about 100,000 years). These considerations allowed us to claim that Quaternary glacial periods follow one another at the same interval as the main coal seams of Pliocene. However, they tend to reflect the cooling phases of the same shorter cycles of the orbital eccentricity. Consequently, we can establish that the banks of the main coal seams reflect directly the precessional cycle (with a period of about 26,000 years).

\section{CONCLUSIONS}

We believe that the identification of the Valach cycle (with its relatively large period of 4.1 m.y.) represents a great achievement of the Romanian geological research school, given the current developments of sequential analysis of sedimentary deposits with its characteristic wide range of various cycles. We think this achievement is furthermore enhanced by the fact that in justifying this new cycle, a new and very plausible cosmic movement (pulsation of Solar system) has been identified, this too representing a world research premiere.

The identified succession of warming and cooling phases of the Valach cycle allows a more easy explanation of a large number of geological data, thus opening new perspectives in justifying a vast succession of geological phenomena, which has been, until now, unsatisfactorily explained. The corroboration of a large number of lithological sequences of the same nature (i.e. Senonian-Cainozoic coal complexes) for a comparatively large period as opposed with the minimum 86 m.y. of the Valach cycle offers no doubt as to the latter's real existence, the same applying to the Solar system pulsation (i.e. "The Valach pulsation").

Consequently, we believe that Romanian geological research school should continue the studies in this field, on one hand by adding new supporting data for the mentioned interval (Santonian-Pliocene) and also for the cooling phases shown in the red and scarlet coarse deposits, and on the other hand, by extending the research towards older geological periods (i.e. Lower Cretaceous, Liasic, etc). Moreover, we consider that the research should be also furthered in other fields than geology, particularly in physics and astronomy, burden to be borne primarily, we think, by the contemporary Romanian science. 


\section{REFERENCES}

Moisescu V. 1990, Sea Level Changes in NW Transylvania during the Eocene. Revue Roumaine de Géologie, Géophysics and Géographie, Géologie, 34, pp. 41-46, Bucharest.

Moisescu V. 1994, Formatiunile eocen superioare-miocen inferioare din NV-ul Transilvaniei si ciclurile globale de sedimentare. Studii si cercetă ri, Geologie, 39, pp. 83-93, București.

Steininger F. F., Senes J., Kleeman K., Röegl F. 1985, Neogene of the Mediterranean Tethys and Parathetys - I.G.C.P. Project 25, Vienna.

Steininger F. F., Röegl F., Hochuli P., Müller C. 1988, Lignite deposition and marine cycles. The Austrian Tertiary lignite deposits: a case history. Sitzungsberichten O.W.A. Math., Natur., 197, Vienna.

Țicleanu M., Țicleanu N., Diaconiț ă D., Pauliuc S. 1998, The temporal content of the Neogene coal generating cycles in Romania. Romanian Journal of Stratigraphy, 79, pp. 107-117, București.

Țicleanu M. 1999, Studiul structurii si evoluț iei geologice a parții vestice a Bazinului Dacic (Oltenia) in etapa carbogeneratoare pliocenă (dacian-romaniană ). Doctoral Thesis, Bucarest University, University Library, București.

Țicleanu M., Vass D., Țicleanu N., Royik P., Marinescu FI., Dinulescu C., Pauliuc S. 2001, The main role of the Walachian climatic cycle $(4.1 \mathrm{Ma})$ in the forming of Neogene coal complexes of Central Parathetys. 9 th Cool Geology Conference, abstract, Prague.

Țicleanu M., Țicleanu N., Constantin P., Pauliuc S., Marinescu FI., 2002, The Essential Role of the Valach Climatic Cycle (4,1 M.y.) in the Occurrence and Development of the Senonian and Cainozoic Coal Facies in Romania, GEO-2002, Sesiunea Știint ifică Anuala a Societă ții Geologice a Romaniei, vol. abstracte, pp. 51-52, București. 